\title{
JUDICIAL REVIEW OF ICC SECURITY AUTHORIZATIONS: THE RELEVANCE OF UNAPPROVED CONTROL*
}

SECTION 20a of the Interstate Commerce Act empowers the ICC to authorize stock issues considered compatible with the public interest. ${ }^{I}$ While the statutory standards reflect a predominant congressional intent that the Commission judge a financing's effect on the service offered by the carrier, ${ }^{2}$ courts have recognized a co-ordinate duty to protect investors. ${ }^{3}$ Since the Commission must thus discharge a dual obligation, factors inappropriate in agency proceedings designed primarily to safeguard investors are germane to

*Alleghany Corp. v. Breswick \& Co., 26 U.S.L. WeEK 4116 (U.S. Jan. 27, 1958).

1. 41 Stat. 494 (1920), as amended, 49 U.S.C. $\$ 20 \mathrm{a}$ (1952). The Commission may authorize a carrier stock issue under $\$ 20 \mathrm{a}$ if it finds that such issue "is for some lawful object within its corporate purposes, and compatible with the public interest, which is necessary or appropriate for or consistent with the proper performance by the carrier of service to the public as a common carrier, and which will not impair its ability to perform that service, and . . . is reasonably necessary and appropriate for such purpose." Section 20a and all other sections of the Interstate Commerce Act are to be administered in a manner best implementing the national transportation policy: ". . . to provide for fair and impartial regulation of all modes of transportation subject to the provisions of this Act, so administered as to recognize and preserve the inherent advantages of each; to promote safe, adequate, economical, and efficient service and foster sound economic conditions in transportation among the several carriers . . ." 54 Stat. 899 (1940), 49 U.S.C. National Transportation Policy (1952); see ICC v. Parker, 326 U.S. 60, 66 (1945).

2. See Statement of Commissioner Clark, 1. Hearings Before the House Committee on Intcrstate and Foreign Commerce, 66th Cong., 1st Sess. 98-99 (1919): "Under this bill the carrier asking for the approval of an issue of either bonds or stocks would state the purpose for which it desired the money, and the commission would have the power to approve or disapprove the issue. . . Rep. Parker: I am entirely in accord with your controlling the issues of stocks and other obligations, but the theory, of course, upon which you are granted that power over the issues of stock and other obligations is whether or not the purpose stated is a legitimate one within the powers of the carrier. Comm. Clark: And one which is needed in the proper performance of its public service, and one that will contribute to the better service and convenience of commerce." See also H.R. Rep. No. 681, 63d Cong., 2d Sess. (1914); 3-A Sharfiran, The Interstate Commererce Comusssion 504 (1935): "It is clear that the financial organization of the carriers was placed under the close supervision of the Commission, and with but scant recognition of the principles and policies to be applied in the exercise of its regulatory power." Further, the statutory authorization of $\$ 20$ a gave the courts and Commission little idea of how major a reform of carrier finance was intended. 3-A $i d$. at 623 .

3. See, e.g., Otis \& Co. v. Pennsylvania R.R., 61 F. Supp. 905, 910 (E.D. Pa. 1945), where the court commented on the ICC's recognition that different standards were applicable in its determinations, depending on whether the interest of the public or of the private stockholder was involved: "There may, indeed, be a real difference between what is required in the public interest and what is necessary to satisfy stockholders . . ." Cf. Cleveland, C., C. \& St. L. Ry. v. Jackson, 22 F.2d 509, 511. (6th Cir. 1927) (Commerce Act "requires that the interest of the stockholder be considered and protected"); Schwabacher v. United States, 334 U.S. 182 (1948) (merger terms must be just and reasonable 
the disposition of a carrier's application for stock authorization. ${ }^{4}$ The difficulties of resolving authorization requests are increased when courts hold

to all groups of stockholders). For examination of the limited standing afforded shareholders to contest ICC orders, see notes 28,45 infra.

Prior to the enactment of $\S 20 \mathrm{a}$, the Commission had recognized the need for investor protection in carrier securities. See Consolidations and Combinations of Carriers, 12 I.C.C. 277,306 (1907) (carrier securities should be safe and conservative investments); New England Investigation, 27 I.C.C. 560, 616 (1913) (securities of one carrier acquired by another should be a safe investment); Eastern Advanced Rate Case, 20 I.C.C. 243, 259-60 (1911) (ICC, in rate case, to take into account possible effect of rate setting on long-standing good-faith investments). Subsequently, the particular interests of investors received closer attention. See, e.g., Tenn. Cent. Ry., 105 I.C.C. 609 (1926) (refusal to authorize issuance of preferred stock with only contingent voting power); Pittsburgh \& W. Va. Ry., 105 I.C.C. 552 (1926) (same); Roscae, Snyder \& Pac. Ry., 175 I.C.C. 602, 603 (1931) (provision that conversion rights of preferred stock governed by board of directors should be made clear to shareholders) ; Associated Transp., Inc., 38 M.C.C. 137 (1942) (ICC approval of particular method of selling stock required to protect the investing public unfamiliar with motor carrier securities); Chesapeake \& O. Ry., 254 I.C.C. 653,657 (1943) (value of property supporting stockholders' equity examined) ; cf. Western Md. Ry., 290 I.C.C. 445,462 (1954) (ICC required to protect the interests of each class of shareholders in securities modification plan). Nevertheless, the safeguards afforded investors by $\S 20 \mathrm{a}$ are indirect. The Commission's authority over carrier financial structure and practices was "designed, indirectly, to protect the investing public against the dissipation of railroad resources through faulty or dishonest financing . ..." 1 SHARFman, The Interstate Commerce Commission 190 (1931). See also Loss, Securities REguLatToN 67 (1951).

4. For factors considered by the ICC, see, e.g., Kansas City So. Ry., 271 I.C.C. 403 , 413 (1948) (public interest concerned with compensation paid to financial advisors in issue and sale of railroad securities) ; Alexander R.R., 267 I.C.C. 421, 422 (1947) (proposed issue with par value of $\$ 1$ a share not compatible with the public interest); New York, N.H. \& H.R.R., 220 I.C.C. 505, 615 (1937) (authorization denied issue designed for the purpose of acquiring property not to be used in the operations of a railroad); Chesapeake \& O. Ry., 180 I.C.C. 699,700 (1932) (conservation of carrier credit is a matter of public interest) ; Lehigh Valley R.R., 180 I.C.C. 46, 47 (1931) (pledge of bonds under continuing loan agreements with banking companies not in the public interest). See also Casey v. Woodruff, 49 N.Y.S.2d 625 (Sup. Ct. 1944) (ICC may reject offerings as improvident, if issue would reduce ability of carrier to render public service).

The Securities Act of 1933, 48 STAt. 74 (1933), as amended, 15 U.S.C. $\$ \$ 77 a-77 a a$ (1952), was designed to inform the investor of the facts concerning securities offered for sale and to protect him against fraud and misrepresentation. See S. REP. No. 47, 73d Cong., 1st Sess. (1933). See also Davis, Adarimistratuve Law 150 (1951); Loss, Securities Regulation 120-26 (1951) ; Douglas \& Bates, The Federal Securitics Act of 1933, 43 Y ALE L.J. 171 (1933). The Investment Company Act of 1940, 54 StAT. 789 (1940), as amended, 15 U.S.C. $\$ \$ 80 \mathrm{a}-1$. to -52 (1952), more regulatory in nature than the Securities Act of 1933, was designed to provide an atmosphere conducive to management in the best interests of shareholders. But the Securities and Exchange Commission has no wide discretionary power under the Investment Company Act like that of the ICC to approve or prohibit stock issuances. See Motley, Jackson \& Barnard, Fedcral Regulation of Investment Companies Since 1940, 63 HARv. L. REv. 1134 (1950); Jaretzki, The Investment Company Act of 1940, 26 WasH. U.L.Q. 303 (1941). The Public Utility Holding Company Act, in contrast to the Securities Act, looks to the avoidance of injury to consumers as well as to investors. Public Utility Act of 1935, 49 Stat. 803 (1935), 
that protection of the consuming public or investors requires correct determination of questions of law collateral to such proceedings. ${ }^{5}$

The protracted litigation between Alleghany Corporation and Breswick \& Co. exemplifies these difficulties. ${ }^{6}$ Alleghany, an investment company, acquired control of the New York Central Railway System through a proxy contest in 1954 without securing ICC approval. ${ }^{7}$ When the Central system later

as amended, 15 U.S.C. $\S \S 79-79 z$ (1952) ; see S. Rep. No. 621, 74th Cong., 1st Sess. 28 (1935). State blue sky laws are designed to protect the public investor. BaLrantine, Corporations 860 (rev. ed. 1946). For a survey of state laws, see Loss \& Cowetr, BluE Sky Laws (1958); BaLLANTINE, op. cit. supra at 858-73.

5. The Commission has found it an imposing task to reconcile local interests and effectuation of the broad aims of the national transportation policy. See 2 SHARFMan, The Interstate CoMraierce CoMmission 247-58 (1931). See, generally, Lockin, Regulation of Security Issues by the Interstate Commerce Commission (1925); cf. McLean Trucking Co. v. United States, 321 U.S. 67 (1944) (Congress left the ICC free to resolve the complex considerations involved in carrier consolidations); MooRE, REorganization of Railroad Corporations 157-59 (1941). See also Herring, Public Administration and the Public Interest 183 (1936): "The milieu is distinctly one of special interests, and the regulatory body lives in an environment of conflicts. It must function here, not in accordance with thin, vague concepts, but in terms of concrete situations where the real content of the public interest must be extricated from a maze of technical detail."

6. Breswick \& Co. v. United States, 134 F. Supp. 132 (S.D.N.Y.), aff'd, 138 F. Supp. 123 (S.D.N.Y. 1955), rev'd and remanded sub. nom. Alleghany Corp. v. Breswick \& Co., 353 U.S. 151, on remand sub. nom. Breswick \& Co. v. United States, 156 F. Supp. 227 (S.D.N.Y. 1957), rev'd per curiam and remanded stb. nom. Alleghany Corp. v. Breswick \& Co., 26 U.S.L. WeEK 4116 (U.S. Jan. 27, 1958).

7. Organized in 1929 with a charter providing for extensive investment powers, Alleghany registered in 1940 with the SEC as an investment company, under $\S 80 a-3$ (a) of the Investment Company Act. 54 STAT. 797 (1940), 15 U.S.C. $\$ 80 \mathrm{a}-3$ (a) (1952). However, in 1945, after acquiring control of more than one rail carrier, it became subject to the jurisdiction of the ICC. Chesapeake \& O. Ry., 261 I.C.C. 239 (1945). The SEC therefore relinquished its jurisdiction. Alleghany Corp., 20 S.E.C. 731 (1945). In 1954, after divesting itself of all carrier control, Alleghany conducted a successful proxy fight for control of the New York Central Railway System. See N.Y. Times, June 12, 1954, p. 27, cols. 5-8. The incumbent Central management sought, without success, an ICC declaratory ruling that control of Central by Alleghany would violate $\$ 5(2)$ of the Interstate Commerce Act. I.C.C. Fin. Doc. No. 31535, May 18, 1954; see Louisville \& J. Bridge \& R.R., 290 I.C.C. 725, 730-31 (1955). Section 5(2) provides: "It shall be lawful, with the approval and authorization of the Commission, as provided in subdivision (b) -(i) for two or more carriers to consolidate or merge their properties or franchises, or any part thereof, into one corporation for the ownership, management, and operation of the properties theretofore in separate ownership; or for any carrier, or two or more carriers jointly, to purchase, lease, or contract to operate the properties, or any part thereof, of another; or for any carrier, or two or more carriers jointly, to acquire control of another through ownership of its stock or otherwise; or for a person which is not a carrier to acquire control of two or more carriers through ownership of their stock or otherwise; or for a person which is not a carrier and which has control of one or more carriers to acquire control of another carrier through ownership of its stock or otherwise . . ." 24 Stat. 380 (1887), as amended, 49 U.S.C. $\$ 5$ (2) (a) (1952). Section 5 (2) (b) prohibits the Commission from entering an order approving a proposed trans- 
obtained control of another carrier, ${ }^{8}$ Alleghany successfully sought carrier status under section 5(3), which permits the ICC to subject investment and holding companies controlling carriers to section 20a's security requirements. ${ }^{9}$ Pursuant to the authority so established, the Commission authorized an Alleghany stock issue. Subsequently, a three-judge district court enjoined the issue on the ground that the ICC status order was invalid and that the

action within the scope of $\S 5(2)$ (a) "unless it finds that the transaction proposed will be consistent with the public interest." 24 STAT. 380 (18S7), as amended, 49 U.S.C. $\$ 5$ (2) (b) (1952). The Central management argued that, without prior commission approval, an acquisition of Central control by Alleghany would violate $\S 5(2)$. See Louisville \& J. Bridge \& R.R., supra at 730-31.

8. In September 1954, after the ICC had issued a show-cause order to Alleghany which contemplated cancellation of the 1945 carrier status order, Alleghany applied with Central for permission to merge the Louisville \& Jeffersonville Bridge \& Railroad Company into the "Big Four," a carrier controlled by Central. Alleghany, in addition, requested continuation of its carrier status. The SEC intervened, requesting jurisdiction over Alleghany, and suggested that the carrier status order of 1945 should no longer be in effect. I.C.C. Fin. Doc. No. 18656, Sept. 24, 1954. The petition to intervene of Breswick \& Co., a common stockholder of Alleghany, was denied. I.C.C. Fin. Doc. No. 18656, Feb. 15, 1955. On March 2, 1955, Division Four of the ICC cancelled the 1945 status order, found that Central was controlled by Alleghany, approved the merger of Jeffersonville into the Big Four, recognized Alleghany's control of Jeffersonville through the agency of Central and held that Alleghany was to be "considered as a carrier" subject to the provisions of $\$ 20$ a. Louisville \& J. Bridge \& R.R., supra note 7, at 747. On reconsideration, the full Commission granted both the petitions of the SEC and Breswick to intervene but denied a hearing. It approved the report of Division Four but differed on the interpretation of $\$ 5(2)$, requiring a noncarrier to obtain ICC approval prior to acquiring more than one carrier. See note 7 supra. It stated that acquisition of control of an integrated rail system was not the acquisition of more than one carrier within the meaning of the act and thus not a transaction requiring its approval. Louisville \& $\mathrm{J}$. Bridge \& R.R., 295 I.C.C. 11 (1955).

9. 24 STAT. 380 (1887), as amended, 49 U.S.C. \$ 5(3) (1952): "Whenever a person which is not a carrier is authorized, by an order entered under paragraph (2) . . , to acquire control of any carrier or of two or more carriers, such person thereafter shall, to the extent provided by the Commission in such order, be considered as a carrier subject to such of the following provisions as are applicable to any carrier involved in such acquisition of control: ... sections $20 \mathrm{a}(2)$ to (11), inclusive .... In the application of such provisions of section $20 \mathrm{a} \ldots$ the Commission shall authorize the issue or assumption applied for only if it finds that such issue or assumption is consistent with the proper performance of its service to the public by each carrier which is under the control of such person, that it will not impair the ability of any such carrier to perform such service, and that it is otherwise consistent with the public interest."

When a noncarrier investment company acquires carrier status, it is no longer subject to the Investment Company Act. 54 STAT. 799 (1940), 15 U.S.C. $\$ 80 a-3(c)$ (9) (1952). The SEC, in intervening to request jurisdiction over Alleghany, claimed that congressional policy would best be effected if the ICC revoked its 1945 status order. It viewed Alleghany as primarily engaged in the business of investing, reinvesting or trading in securities and felt that, notwithstanding the alleged control of Central, public investors required the protections of the Investment Company Act. Memorandum of the SEC, I.C.C. Fin. Doc. No. 14692, Sept. 14, 1954; Transcript of Record, p. 191, Alleghany Corp. v. Breswick \& Co., 353 U.S. 151. (1957) (hereinafter cited as Record). 
Securities and Exchange Commission accordingly had exclusive jurisdiction over the offering. ${ }^{10}$ The court, overruling the ICC interpretation, construed

10. Breswick \& Co. v. United States, 138 F. Supp. 123 (S.D.N.Y. 1955). Alleghany proposed to issue $1,367,440$ shares of $6 \%$ convertible preferred stock in exchange for its outstanding shares of $5 \mathrm{I} / 2 \%$ preferred stock and $14,768,352$ shares of common stock upon conversion of the convertible preferred. For a detailed discussion of the offering, see Alleghany Corp., I.C.C. Fin. Doc. No. 18866, May 26, 1955, Record, p. 518. Breswick attacked the issue both in the courts and before the Commission. A brief history of the proceedings follows:

February 8, 1955-Proposed exchange approved at special meeting of Alleghany shareholders. Record, p. 520 .

February 18, 1955-Alleghany applies to ICC seeking a \$20a authorization. Record, p. 371. March 2, 1955-Division Four grants Alleghany carrier status. Louisville \& J. Bridge \& R.R., 290 I.C.C. 725 (1955).

March 28, 1955-Randolph Phillips, a holder of Alleghany common stock, files petition for leave to intervene before the ICC and asserts lack of commission jurisdiction over, and unfairness of, the issue. Record, p. 478.

April 6, 1955-Breswick \& Co. denied injunction by district court, and directed first to exhaust its administrative remedies before the ICC. Breswick \& Co. v. Briggs, $130 \mathrm{~F}$. Supp. 953 (S.D.N.Y. 1955).

April 11, 1955-Breswick files amended petition to intervene before the ICC. Record, p. 489.

April 20, 1955-Breswick and Phillips permitted to intervene, but no hearing assigned. Record, p. 508.

May 24, 1955-Full Commission affirms Division Four's order granting Alleghany carrier status. Louisville \& J. Bridge \& R.R., 295 I.C.C. 1.1 (1955).

May 26, 1955-Division Four approves the stock issue. I.C.C. Fin. Doc. No. 18866, May 26, 1955, Record, p. 518.

June 22, 1955-Full Commission denies reconsideration of order authorizing stock issue. Order effective immediately. Alleghany Corporation, I.C.C. Fin. Doc. No. 18866, June 22, 1955, Record, p. 554.

June 23, 1955-Alleghany begins to carry out the exchange. District Judge Dimock issues temporary restraining order after 900,000 shares issued. Record, p. 56.

July 13, 1955-Breswick amends complaint filed in district court on June 6,1955 , contesting status order, to include attack on ICC stock authorization orders of May 26 and June 22. Record, p. 94.

July 21, 1955-Preliminary injunction granted by three-judge court, Hincks, C.J., dissenting. Breswick \& Co. v. United States, 134 F. Supp. 132 (S.D.N.Y. 1955).

August 3,1955-Circuit Justice Harlan stays injunction as to the 900,000 shares already issued. Breswick \& Co. v. United States, 75 Sup. Ct. 912 (1955). Trading, however, suspended on the New York Stock Exchange. See Alleghany Corp. v. Breswick \& Co., 353 U.S. 151,159 n.4 (1957).

November 18, 1955-Injunction made permanent. Breswick \& Co. v. United States, 138 F. Supp. 123 (S.D.N.Y. 1955).

November 30, 1956-After Alleghany had registered with the SEC, reserving the right to continue litigation, the SEC denies Alleghany application for stock approval under the Investment Company Act. Alleghany Corp., 1952-56 CCH FEd. SEc. L. REP. 776418 (SEC 1956).

The Commission's orders are subject to review by specially constituted three-judge district courts. 28 U.S.C. $\$ \$ 22 \$ 4,2325$ (1952). Appeais from these courts may be taken 
section 5(2), requiring ICC approval prior to noncarrier acquisition of control over two or more carriers, as applying to the acquisition of a single railway system. ${ }^{11}$ It held that such approval was prerequisite to ICC jurisdiction and that neither de facto control of a system nor the approved merger of another carrier into the system sufficed. ${ }^{12}$ On direct appeal, the Supreme Court found that Alleghany's control over the Central system and Central's approved control of another carrier supported commission jurisdiction. It declined, however, to resolve the conflict over the interpretation of section $5(2)$ and remanded for consideration of claims that the stock issue violated the provisions of the Interstate Commerce Act. ${ }^{13}$

directly to the Supreme Court. 28 U.S.C. $\$ 1253$ (1952); see text at note 13 infra; cf. United States v. Griffin, 303 U.S. 226, 233 (1938) : "In the opinion of Congress jurisdiction with the extraordinary features of the Urgent Deficiencies Act was justified by the character of the cases to which it applied-cases of public importance because of the widespread effect of the decisions thereof." See also Davis, op. cit. supra note 4, at 725. For a criticism of this method of reviewing agency determinations, see Developments in the Law-Remedies Against the United States and Its Officials, 70 HARv. L. REv. 827, 902-03 (1957).

11. Breswick \& Co. v. United States, 138 F. Supp. 123, 137-38 (S.D.N.Y. 1955). See also Breswick \& Co. v. United States, 134 F. Supp. 132 (S.D.N.Y. 1955) (granting preliminary injunction). For text of $\S 5(2)$, see note 7 supra. The full Commission had viewed the acquisition of an integrated railroad system as a transaction not within the scope of $\$ 5(2)$ and thus not requiring ICC approval. It argued that the concern of $\$ 5(2)$ was with the unification of carriers under common control and management, rather than shifts in the identity of the controller in no manner effecting carrier consolidation. Louisville \& J. Bridge \& R.R., 295 I.C.C. 11 (1955). Division Four, on the other hand, had contended that, in accordance with past commission practice, control of a single system might not lawfully be acquired without prior ICC approval. Louisville \& J. Bridge \& R.R., 290 I.C.C. 725,733 (1955). The district court noted that where an agency is inconsistent in its statutory interpretation, courts give little or no weight to the determination. Breswick \& Co. v. United States, 138 F. Supp. 123, 128 n.6 (S.D.N.Y. 1955).

12. Id. at 128,135 . The court reasoned that the Commission could not subject Alleghany to its jurisdiction for the purposes of stock issuance without first approving Alleghany's alleged control of Central. Thus, while the court questioned the existence of that control, it felt that even were control present, the absence of the necessary ICC approbation was sufficient ground to deny Alleghany carrier status. Ibid. Furthermore, Alleghany control over Central assumed, the Jeffersonville merger was not thought to constitute an "acquisition of control" within the meaning of $\S 5(2)$; hence the ICC order authorizing the acquisition was a nullity. Since the 1955 carrier status order was thus invalid, and the 1945 status order had been expressly terminated, see note 8 supra, the court concluded that Alleghany was subject to SEC regulation under the Investment Company Act. For a discussion of the problem of the jurisdictional conflict between the ICC and the SEC, see Comment, Regulation of Railroad Holding Companies Under the Investment Company Act: The Alleghany Case, 6 Dure B.J. 1 (1956).

13. Alleghany Corp. v. Breswick \& Co., 353 U.S. 151 (1957). The Court first held that Breswick had standing to attack the status order, since if it was invalid the ICC would not possess jurisdiction to approve the stock issue alleged to be unfair. Id. at 15960. It then examined the control relationships between Alleghany and Central, and Central and Jeffersonville, and found that Alleghany did in fact control Central, and, through that control, Jeffersonville. Id. at 165, 171. The acquisition of Jeffersonville was held a 
Although finding these claims without merit, the district court continued the injunction. ${ }^{14}$ Adhering to its interpretation that prior ICC approval was essential to lawful acquisition of a system, the court deemed Alleghany illegally in control of Central. ${ }^{15}$ Moreover, though Breswick had failed to raise the point, it held that the stock authorization should await either approval of control, to eliminate the possibility of divestiture, ${ }^{16}$ or a specific commission finding that, despite this danger, immediate issuance would be in the public interest. ${ }^{17}$ Nevertheless, perhaps in view of the ICC's position that no ap-

transaction within the scope of $\$ 5(2)$. Id. at 171 . Thus, since Alleghany controlled more than one carrier, the status order was justified, and the ICC had the power to rule on the stock issue. The necessity of approved control of Central was held irrelevant to the Commission's jurisdiction. "The Commission and Alleghany contend that Commission approval of the acquisition of a single, integrated system is not necessary. We need not decide this question, however, and intimate no opinion on it, for even if such approval is necessary, the statutory requirement of 'a person which is not a carrier and which has control of one or more carriers' refers to 'control' and not to 'approved control.' There seems to be no reason to read in the word 'approved.' Such a holding would mean that the failure of a company engaged in a transaction requiring Commission approval to apply for that approval would deprive the Commission of jurisdiction." Id. at 161-62. Thus, while de facto control of Central was determined to be in Alleghany, the legality of that control was not decided. The case was remanded for "consideration by the District Court of appellees' claim, not previously discussed, that the preferred stock issue as approved by the Commission was in violation of the Interstate Commerce Act." Id. at 175 .

14. Breswick \& Co. v. United States, 156 F. Supp. 227 (S.D.N.Y. 1957). Claiming that the proposed offering was unfair to common stockholders and that the Commission's findings on that point were inadequate, Breswick argued that the value of the old preferred was overestimated, the new preferred underestimated. Conversion of the new preferred, then, would operate to dilute the common stock. Brief for Plaintiffs, ibid. The district court held the Commission's findings adequate, and disposition of these claims to be within the range of the agency's expert judgment. Id. at 230. It also rejected Breswick's contention that dissenting shareholders were entitled to an evidentiary hearing before the Commission. Ibid.

15. Id. at 232, 233. Alleghany's control of Central was deemed to violate $\S 5(4)$ of the Interstate Commerce Act as a matter of law. The section provides that the effecting of "the control or management in a common interest of any two or more carriers" in any way other than as provided by $\S 5(2)$ shall be unlawful. 41 Star. 481 (1920), as amended, 49 U.S.C. $\$ 5(4)$ (1952). The court reiterated its view that control of a system requires prior commission approval, for it interpreted a system as consisting of more than one carrier within the meaning of $\S 5(2)$.

16. Breswick \& Co. v. United States, 156 F. Supp. 227, 235 (S.D.N.Y. 1957). Breswick had not argued the relevance of divestment possibilities, resulting from unlawful carrier control, before the Commission, see note 17 infra, nor briefed the point on remand to the district court, Brief for Plaintiffs, Breswick \& Co. v. United States, supra.

17. Breswick \& Co. v. United States, supra note 16, at 235. "As long as Alleghany's control of Central is unapproved, it is subject to injunction, divestiture and other sanctions.... To say the least, it would be arbitrary to authorize the issue without even considering the effect of divestiture upon the value of this important asset as long as that action remains a possibility." Id. at 233, 234. The court reasoned that protection of potential investors in the new preferred barred issuance until this "cloud" upon the stock's value was lifted. Id. at 233. However, since the proposed issue was not designed for new in- 
proval was necessary under section $5(2)$, the court did not remand for commission action. ${ }^{18}$ On appeal, the Supreme Court reversed, and, in a per curiam opinion, remanded in language identical to that of its original mandate. ${ }^{19}$

The summary reversal implied that the district court exceeded the bounds of the previous remand in re-emphasizing Alleghany's unapproved control of Central. It did not specify, however, whether the remand was violated because illegal control could not be argued initially in the district court, ${ }^{20}$ be-

vestors but existing shareholders, see note 10 supra, who would be equally injured by divestiture whether they held new or old certificates, the protection envisioned by the district court appears illusory.

The injunction, furthermore, was held necessary to protect the interests of the consumer. The court argued that since the possibility of divestment was not considered by the Commission in approving the stock, the. $\$ 20 \mathrm{a}$ findings were necessarily inadequate. The authorization would, in view of the illegal control, conflict with the ICC's settled policy of compelling prompt application for approval of control where required. Breswick \& Co. v. United States, stpra note 16, at 235. Moreover, the granting of stock authorizations prior to approving control resulted in arbitrary and capricious agency action, and such "piecemeal" authorizations would preclude, as a practical matter, divestiture in the future. Id. at 236, 237. But see note 33 infra for cases where the ICC disposed of outstanding violations of $\$ 5(2)$ before proceeding to other regulatory determinations.

18. Breswick \& Co. v. United States, 156 F. Supp. 227, 237 (S.D.N.Y. 1957). Under the Urgent Deficiencies Act, 28 U.S.C. $\S \S 2321-25$ (1952), a three-judge court is limited in relief to setting aside or enjoining the ICC's order and remanding the cause for further consideration. See United States v. Jones, 336 U.S. 641, 672-73 (1949).

19. Alleghany Corp. v. Breswick \& Co., 26 U.S.L. WeEk 4116 (U.S. Jan. 27, 1958) : "[T] he case is remanded for consideration . . . of the only claim that was left open at this Court's prior disposition of this litigation, to wit, whether 'the preferred stock issue as approved by the (Interstate Commerce) Commission was in violation of the Interstate Commerce Act.",

Three Justices dissented, viewing the district court's ruling as within the scope of the previous remand. Mr. Justice Douglas, the spokesman, stated: "No one . . . should be confused by the fact this Court held approval of the acquisition was not necessary under the facts of this case for one reason (jurisdiction) and the District Court held approval was necessary for another reason (compliance with the Act before the stock could be issued)." Id. at 4118. In particular, the minority objected to the "broken-field running" characterizing the procedure permitted Alleghany by the Commission. Id. at 4119 . The phrase indicates the minority had accepted the district court's interpretation of "system" and viewed discussion of that point appropriate.

The recent dismissal of the injunction by the district court terminated the litigation. See N.Y. Times, March 28, 1958, p. 37, col. 4. The court reaffirmed its view that the stock issue complied with the Commerce Act's requirements. See note 14 supra.

20. Breswick had failed to raise the threat of divestiture as a bar to issuance. Sea note 16 supra. Judicial review of agency action is limited to allegations of error made before the agency in the first instance. See United States v. Tucker Truck Lines, 344 U.S. 33 (1952) (objection to ICC procedure first raised in three-judge district court may not be considered by that court); Carolina Scenic Coach Lines v. United States, 56 F. Supp. 801, 804 (D.N.C.), aff'd, 323 U.S. 678 (1944) (objection to ICC grant of certificate of convenience and necessity raised initially before three-judge court not judicially cognizable) (dictum) ; Colorado Radio Corp. v. FCC, 118 F.2d 24 (D.C. Cir. 1941) (party cannot object that Commission failed to consider a factor which was not pre- 
cause that court had improperly raised the issue on its own motion ${ }^{21}$ or because prior approval was not necessary to the stock authorization. ${ }^{22}$ The decision thus fails to establish the procedure to be followed in similar cases and invites relitigation of the issues in Alleghany. ${ }^{23}$

The Court's silence also leaves unanswered the district court's arguments that approval of control is essential to investor and consumer protection from a subsequent stock issue. ${ }^{24}$ Undoubtedly, the elimination of divestment possibilities affords shareholders a more secure investment. ${ }^{25}$ Further, where control must be approved, a judicial requirement that approval precede authorization of an issue would force carriers to seek a determination of the desirability of continued control, thus countering possible ICC laxity in investigating illegal acquisitions. ${ }^{26}$ Finally, linking section $5(2)$ to section $20 \mathrm{a}$ may

sented to agency prior to decision). See also Hutchinson v. Fidelity Inv. Ass'n, 106 F.2d 431, 436 (4th Cir. 1939) : "An appellate court ... cannot assume the functions of a special master and roam at large over the record, and any attempt . . . to do so would probably do a great deal more harm than good."

21. Not only had the ICC, the tribunal of the first instance, no opportunity to formulate a reply to the argument that divestment threats constitute a bar to stock issuance, but the litigant Alleghany was similarly unaware and thus unprepared. $C f$. United States v. Hancock Truck Lines, 324 U.S. 774, 779 (1945) (reviewing court could not reverse ICC order on ground urged before Commission but waived for purposes of appeal) ; 3 AMr. Jur., Appeal and Error $\$ 812$ (1936) (no search will be made by a court for additional grounds for reversal).

22. Such a holding would, of course, have disposed of the merits of the case.

23. For example, where a carrier clearly subject to the Commission's jurisdiction attempts a stock issuance, the right of a stockholder to allege a previous acquisition of carrier control, unapproved by the ICC, as a ground for denying authorization remains in question. Alleghany itself is currently requesting approval for a new security issuance. See N.Y. Times, Feb. 22, 1958, p. 20, col. 1. The same objections could conceivably be made to this offering as were made to that in the principal case.

24. See note 17 supra. The district court distinguished the harm threatening the potential investors in Alleghany's new preferred stock from that facing the general public. In the absence of explicit rationalization for ignoring the control question in a $\S 20$ a proceeding, the court felt that the ICC's action would be capricious and arbitrary. Breswick \& Co. v. United States, 156 F. Supp. 227 (S.D.N.Y. 1957). A court may properly set aside an agency order held capricious. Shields v. Utah Idaho Cent. R.R., 305 U.S. 177, 185 (1938) ; cf. Mississippi Valley Barge Line Co. v. United States, 292 U.S. 282, 286-87 (1934).

25. Divestiture is recognized as a harsh procedure. See note 29 infra. In its potential effects on the value of stock, it is analogous to imminent loss of a substantial lawsuit. The Securities and Exchange Commission has seen the need for investor awareness of pending litigation and has required issuers so to inform the investing public. See note 38 infra. If the expected loss is considerable, existing shareholders may deem it advisable to sell, and potential shareholders to refrain from purchasing. See, generally, Grahad, The Intelitgent Investor (1954).

26. For criticism of the operations of the Commission, see Huntington, The Marasmus of the ICC: The Commission, the Railroads, and the Public Interest, 61 YALE L.J. 467 (1952). But see Morgan, A Critique of "The Marasmus of the ICC: The Commission, the Railroads, and the Public Interest," 62 YALE L.J. 171 (1953). See also Huntington, 
facilitate review of a commission determination that a given shift in control lay beyond the compass of section $5(2) .^{27}$

Rejection of stock offerings, however, is not an effective method of promoting these ends. Unless objection is made to the security issue, opportunity for judicial examination of the existence or propriety of control is not increased. ${ }^{28}$ And imposition of an approval of control requirement could re-

Morgan \& Williams, The ICC Re-examined: A Colloquy, 63 Yale L.J. 44 (1953). For cases where examination of control relationships was delayed, see note 33 infra.

A carrier, contemplating future issuance of stock and fearing objection to the issue on the ground of illegal acquisition of another carrier, would find it advisable immediately to request approval of control in order to avoid the expense and delay of litigation which occurred in Alleghany. Cf. N.Y. Times, Jan. 28, 1958, p. 1, col. 5; id. p. 37, cols. 5, 6. In Alleghany, however, a request for approval would have been useless, since the Commission deemed approval unnecessary as a matter of law. See note 8 supra.

27. A supplementary methad for reviewing $\S 5(2)$ errors might thus be furnished. For the usual way such errors are presented to the courts, see note 28 infra; cases cited note 41 infra.

28. ICC stock authorizations are not subject to judicial review unless a party with standing appeals to a three-judge court. Shareholders may claim unfairness of an issue, but if the Commission's order has a rational basis, and the potential injury to the shareholders' legal rights is questionable, the determination is unassailable. For cases indicating the strict requirements to obtain standing to attack ICC orders in the courts, see Moffat Tunnel League v. United States, 289 U.S. 113 (1933) (appellant had no legal "personality" and thus no rights to contest $\$ 5(2)$ determinations); Alexander Sprunt \& Son v. United States, 281. U.S. 249 (1930) (shipper lacked standing to attack ICC order removing rate differential, since no independent legal right violated by the order); Edward Hines Trustees v. United States, 263 U.S. 143 (1923) (shipper had no right to require carriers to impose penalty charges in the absence of a showing of any legal injury, actual or threatened). See also Mississippi Valley Barge Line Co. v. United States, 292 U.S. 282 (1934) (judicial function exhausted when rational basis found for agency's conclusions) ; Casey v. Woodruff, 49 N.Y.S.2d 625, 648 (Sup. Ct. 1944) (in separate stockholder suit where breach of fiduciary duty is claimed, ICC $\S 20 \mathrm{a}$ order of disapproval should not have res judicata effect; otherwise, Commission would face excessive and spurious objections in $\S 20 \mathrm{a}$ proceedings by intervening stockholders).

Section 20 a would appear intentionally to discourage attacks on ICC stock authorizations. "The jurisdiction conferred upon the commission by this section shall be exclusive and plenary, and a carrier may issue securities and assume obligations or liabilities in accordance with the provisions of this section without securing approval other than as specified herein." 41 STAT. 495 (1920), 49 U.S.C. \& 20a(7) (1952). "[N]o security issued or obligation or liability assumed in accordance with all the terms and conditions of ... an order of authorization . . . shall be rendered void because of failure to comply with any provision of this section relating to procedure and other matters preceding the entry of such order of authorization." 41 STAT. 496 (1920), 49 U.S.C. $\$ 20 a(11)$ (1952). See note 32 infra, discussing the reliance on the ICC, not private interests, to implement the aims of carrier regulation.

ICC control determinations may be attacked independently of $\$ 20$ a proceedings. See The Chicago Junction Case, 264 U.S. 258 (1924) (competitor allowed standing to object to commission approval of carrier control acquisition); cf. Clairborne-Annapolis Ferry Co. v. United States, 285 U.S. 382 (1932) (competitor has standing to object to extension of railroad line); Western Pac. Cal. R.R. v. Southern Pac. Co., 284 U.S. 47 (1931) (same; definite legal right seriously threatened). And investors, too, may contest $\$ 5(2)$ 
strict rather than enhance the likelihood of challenge. Dissenting shareholders, the usual protestants in section 20a proceedings, may fear injury from divestiture and be hesitant to attack control. ${ }^{29}$ Were courts to raise the issue on their own motion, similar fear could deter stockholders from registering any protest. ${ }^{30}$ Again, rejection of offerings seems an undesirable means of coun-

determinations, but only when an independent legal right is threatened. See New York Cent. Securities Corp. v. United States, 287 U.S. 12 (1932) (minority stockholder corporation has standing to contest ICC order authorizing rental dividend payments by lessee carrier in connection with control modification, since its alleged injury was not derivative but independent) ; Stott v. United States, 154 F. Supp. 389, 390-91 (S.D.N.Y. 1957) (minority shareholders have standing to object to $\$ 5$ (2) determinations when exchange of stock occasioned by carrier merger threatens injury; dictum); Pittsburgh \& W. Va. Ry. v. United States, 281 U.S. 479, 487 (1930) (stockholder may have standing to object in some cases of acquisition of control and consolidation; dictum).

Generally, the statutory provisions of the Commerce Act furnish little assistance in determining standing questions. See Davis, Standing to Challenge and to Enforce Administrative Action, 49 CoLUM. L. REv. 759, 772 (1949).

29. The district court, though not specifying the harm divestiture might cause existing or potential shareholders, clearly indicated a belief that the dangers were significant by its ruling barring issuance. Breswick \& Co. v. United States, 156 F. Supp. 227, 23334 (S.D.N.Y. 1957). The possible adverse effects of divestiture on shareholders of the divesting corporation have been noted by the courts. See Louisiana Pub. Serv. Comm'n v. SEC, 235 F.2d 167 (5th Cir. 1956), rev'd, 353 U.S. 368 (1957) (recognition of the possible sizable, if not substantial, loss to the divesting company through an order of divestiture). In Timken Roller Bearing Co. v. United States, 341 U.S. 593 (1951), the Court affirmed the decision of the district court finding a violation of the Sherman Act but reversed a divestiture order. Three members of the majority defended divestiture as within the lower court's discretion. Id. at 601 . Two members of the Court concurred in finding antitrust violations but stated that "since divestiture is a remedy to restore competition and not to punish those who restrain trade, it is not to be used indiscriminately, without regard to the type of violation or whether other effective methods, less harsh, are available." Id. at 603. Mr. Justice Frankfurter, dissenting, adopted the arguments of the concurrence concerning divestiture to support his own contention that no Sherman Act violation had occurred. Id. at 605 . When divestment is ordered, courts may delay enforcement to reduce the injury to the corporation. See Hamilton \& Tili, Investigatron of Concentration of Econonic Power 97 (TNEC Monograph No. 16, 1941). But cf. Report of the Attorney General's National Committee To Study the AntiTRUST Laws 356 (1955) (divestiture has not proved to be a harsh or onerous burden on property).

The remedy of divestiture, as applied by the ICC, would affect carriers with like severity. And the threat of divestment would appear to reduce the attractiveness, and consequently the market value, of a carrier's securities. The danger of divestiture to existing shareholders is clearly no less than that to potential shareholders. The Commission has ordered divestiture in Robert J. Gisinger, 60 M.C.C. 321 (1954); Transcontinental Bus System, Inc., 57 M.C.C. 323 (1951) ; Pacific Greyhound Lines, 56 M.C.C. 415 (1950); see George J. Kolowich, 58 M.C.C. 599 (1952); Thomas M. Mooney, 56 M.C.C. 771 (1950).

30. A court may treat a protesting stockholder as a representative of the public, as well as his own, interest. Where objection is made to a particular stock offering, it could, in the public interest, introduce the possibility of divestiture and thus jeopardize the value of the asset held by the issuing corporation to the detriment of the stockholder. 
tering administrative laxity in the investigation of shifts in control. Commission failure to investigate immediately may be caused by budgetary limitations. ${ }^{31}$ The expedient of examining promptly only those acquisitions thought to threaten injury to the public would be defeated by court decisions compelling indiscriminate scrutiny of all suspect transactions. ${ }^{32}$ Moreover, the Commission in its own discretion has generally examined previously unapproved control before granting other regulatory authorizations. ${ }^{33}$ Thus, the major effect of the district court's decision might not be to encourage earlier commission action but to penalize carriers whose acquisitions the ICC has not deemed to require section 5(2) approval, ${ }^{34}$ or to induce them to demand in-

See note 29 supra. Such a reduction in value may have considerable effect on the stockholder's desire to question stock offerings.

Attacks on corporate security issuances by minority shareholders are viewed with disfavor. See Hornstein, Legal Controls for Intracorporate Abuse-Present and Future, 41 Colum. L. Rev. 405 (1941); Pound, Visitatorial Jurisdiction Over Corporations in Equity, 49 HARv. L. Rev. 369, 395 (1936). On derivative suits generally, see BalLANTINE, CORPORATIONS 333-74 (rev. ed. 1946). If minority actions are to be discouraged, however, a rational method of attaining this end would apply to all such actions, rather than selected cases.

31. The vigorous criticism to which the Commission has been subjected in recent years, see note 26 supra, has been met with assertions of inadequate funds and personnel, see Survey of Organization and Operations of the Interstate Commerce Commission, 20 ICC Prac. J. 358, 370, 389 (1953) (recommending added personnel) ; Arpaia, Criticism of the Commission and Its Work, 20 ICC PRAC. J. 203, 207-08 (1953) (deterioration of personnel status of Commission in recent years due to budgetary limitations).

32. The Commission is given broad discretion in protecting the public interest in carrier acquisitions. "Resolving these considerations [involved in carrier consolidations] is a complex task which requires extensive facilities, expert judgment and considerable knowledge of the transportation industry. Congress left that task to the Commission...." McLean Trucking Co. v. United States, 321. U.S. 67, 87 (1944). Cf. Bonbright, RAILroad Capitalization 153 (1920) (the Transportation Act of 1920 gives "to the regulating commission the widest discretionary powers instead of making specific rules on which decisions must be based"). See also note 48 infra.

33. See cases cited note 29 supra, where the Commission required divestiture. Alternatively, it may authorize continuation of originally unapproved control in the public interest. See, e.g., M. J. Baggett, 11 Fed. Carr. Cas. If 33393 (ICC 1955); H. M. O’Neill, 60 M.C.C. 404 (1954) ; Ernest Capitani, 57 M.C.C. 413 (1951) ; Potomac Coach Lines, Inc., 57 M.C.C. 199, 207 (1950); J. Newton Rayzor, 58 M.C.C. 439, 459 (1952): "Should we deny the application because of the law violation [acquisition without approval], which has now continued for nearly 3 years, and order a divestiture, in all probability a substantial period would elapse before divestiture could be effected, and in all likelihood there would be a severe deterioration in the services ... for which there is a continuing and urgent need. Regardless of the law violation, the public interest is paramount."

34. The Supreme Court enunciated the criteria for determining whether a shift in control necessitated commission approval in the first Alleghany case. "The crux of each inquiry to determine' whether there has been an 'acquisition of control' is the nature of the change in relations between the companies whose proposed transaction is before the Commission for approval. Does the transaction accomplish a significant increase in the power of one over the other, for example, an increased voice in management or operation, or the ability to accomplish financial transactions or operational changes with greater 
dications that control would have been approved had such action been considered necessary. ${ }^{35}$ Such demands by parties fearing subsequent attack on stock offerings would, especially if insignificant control modifications were involved, severely tax ICC operations and perhaps give rise to hasty decisions. $^{36}$

Furthermore, approval of control prior to stock authorization is not necessary to safeguard investors. The degree of protection afforded by the Interstate Commerce Act need be no greater than that of the Securities Act, which protects purchasers by insuring disclosure of all facts essential to informed investor judgment. ${ }^{37}$ When the financial structure of the issuing corporation

legal ease? This is the issue . . ." Alleghany Corp. v. Breswick \& Co., 353 U.S. 151, 169 (1957). See also United States v. Marshall Transp. Co., 322 U.S. 31 (1944) (noncarrier, by use of subsidiaries, gaining control over other carriers is subject to ICC jurisdiction). Despite the efforts of the Court to demarcate the bounds of "acquisition of control," the reach of $\$ 5(2)$ remains uncertain. For cases where the Commission found its approval to be unnecessary, see Great Southern Coaches, Inc., 60 M.C.C. 661 (1954) (not established that applicant is a carrier within the meaning of $\$ 5$ ); Ithaca Transp. Serv., Inc., 65 M.C.C. 5 (1955) (where vendor is not a carrier, purchaser did not obtain carrier status; application for control approval dismissed) ; Universal Carloading \& Distributing Co., 1 Fed. Carr. Cas. If 7490 (ICC 1940) (applicant not a carrier as defined in the act) ; Acme Fast Freight, Inc., 8 M.C.C. 211 (1938) (same); Greyhound Mergers, 1 M.C.C. 342, 351 (1936) (change in form rather than substance does not require ICC approval).

35. Requests for rulings on contingencies by carriers suspecting future interference with financing transactions are likely to be viewed with disfavor by an agency generally quick to safeguard its independence from the judiciary. See Arpaia, The Independent Agency-A Necessary Instrument of Democratic Government, 69 HARv. L. REv. 483 (1956). However, the ICC might not sacrifice the carrier's need for certainty to its own philasophy of regulation. Cf. Louisiana Ry. \& Nav. Co., 99 I.C.C. 357, 358 (1925) (cautioning that certain types of ICC decisions shall not be taken as precedents); INTERSTATE Comarerce Commission Activities, 1887-1937, 167 (1937).

36. Carriers contemplating stock issues would desire to avoid the delay resulting from the investigation and resolution of $\S 5(2)$ questions in a $\S 20$ a proceeding. Thus, disposition of even the most insignificant control modifications might appear advisable. The concomitant increase in commission activity would probably yield general decreased operational efficiency. Cf. Note, 98 U. PA. L. Rev. 70, 77 (1949): "If granting review to a petitioner will open the way for a flood of appeals resulting in hamstringing effective administration of the Act and overloading the court dockets, the court will be reluctant to grant it." Moreover, the demands upon the Commission may be for immediate approval and thus aggravate the investigative burden. See note 31 supra.

37. 48 Stat. 74 (1933), as amended, 15 U.S.C. \$§ 77a-77aa (1952); see note 4 supra. For an analysis of the philosophy of disclosure pervading the Securities Act, see Loss, Securities Regulation 77-82 (1951). Corporations subject to SEC regulation as investment companies are not exempt from the requirements of the Securities Act. See Motley, Jackson \& Barnard, supra note 4, at 1136. Registration under the Investment Company Act is largely an adaptation of the Securities Act's provisions for disclosure, and the remainder of the Investment Company Act's substantive sections consist of statutory prohibitions against issuance in specific cases. In this area, SEC discretion is primarily limited to granting exemptions from the requirements of the act. Id. at 1147. However, carriers and investment companies attaining carrier status are exempted from 
is threatened, the authority of the SEC, administering the Securities Act, is limited to giving purchasers notice of the danger inherent in the offering..$^{38}$ It is so restricted even when the corporation faces possible loss of a major suit, a danger which may be substantially greater than the threat of an ICC divestment order..$^{39}$ Thus, if the possibility of divestiture is disclosed, investor interests should be sufficiently safeguarded. ${ }^{40}$ Existing shareholders contest-

both SEC Investment Company and Securities Act regulation. See 41 STAT. 495 (1920), 49 U.S.C. $\S 20 \mathrm{a}(7)$ (1952); Loss, op. cit. supra at 72. See also note 9 supra.

While arguments have been made that the investor protection afforded by the Interstate Commerce Act should be no less than that given by the Investment Company and Securities Acts, greater safeguards have never been advocated. See Brief for Appellees, p. 27, Alleghany Corp. v. Breswick \& Co., 353 U.S. 151 (1957). And neither the Securities Act nor the Investment Company Act gives the SEC power to refuse authorizations to stock offerings because a threat of divestiture exists. See 48 Stat. 74 (1933), as amended, 15 U.S.C. $\$ \$ 77 a-77 a a$ (1952); 54 STAT. 789 (1940), as amended, 15 U.S.C. $\$ \$ 80-1$ to -52 (1952). Under current standards of investor protection, elimination of divestiture possibilities would, therefore, not appear prerequisite to stock authorizations. Significantly, in the Alleghany litigation, when SEC jurisdiction under the Investment Company Act was assumed, see note 10 supra, neither the SEC staff approving the stock nor the full SEC rejecting it mentioned the lack of approved control and the dangers of divestment, see Alleghany Corp., 1952-56 CCH FED. SEC. L. REP. $\llbracket 76418$ (SEC 1956).

38. 48 StAт. 74 (1933), as amended, 15 U.S.C. $\$ \S 77 a-77 a a ~(1952)$. For a vivid example of the limited authority of the SEC in the absence of fraud or misrepresentation, see Tucker Corp., 26 S.E.C. 249 (1947). The SEC was convinced of the proposed stock's insecure nature and, as a warning to investors, expounded on its speculative aspects. However, since the issuer fulfilled the statutory obligations of disclosure, the stock was released to the public, the SEC emphasizing that it was "in no way passing on the merit or lack of merit of the securities offered ...." Id. at 263; of. Sec. Act Rel. 1, $1 \mathrm{CCH}$ Fed. SEc. L. REP. If 2451.01 (1933). See also Livingston Mining Co., 2 S.E.C. 141 (1937) (corporation must disclose information about pending litigation which may affect rights in firm's assets); Thomascolor, Inc., 27 S.E.C. 151, 155 (1947) ("urging" prospective investors to study carefully the amended prospectus); Consolidated Funds Corp., 2 S.E.C. 724 (1937) (same).

39. Astronomical sums may be claimed as damages in pending civil litigation. See Columbia Gas \& Elec. Corp., 3 S.E.C. 313, 320 (1938) (request under the Holding Company Act, which subjects the issuing corporation to more stringent regulation than the Securities Act, see Loss, Securities Regulation 85-94 (1951), to pay dividends on common stock): "In addition to routine rate and other litigation, there is now pending against applicant and some of its subsidiary companies certain extraordinary litigation, in which large amounts, aggregating approximately $\$ 88,000,000$ are demanded. Naturally the Commission is in no position to express any opinion as to the merits of this litigation, nor does it desire to do so." The loss of such suits would surely upset the financial structure of the issuer. But unlike the loss of civil litigation, divestiture involves at least a partial return of capital. For the threat entailed in divestiture, see note 29 supro.

40. Applied to the Alleghary litigation, this principle would permit the stock to issue. For the investor need only be made aware of dangers which exist at the time of issuance. The possibility of divestiture as a cloud upon the value of the proposed preferred stock was of no significance until the district court's ruling cast doubt on the ICC interpretation of $\$ 5(2)$. See note 11 supra. The threat is thus analogous to that arising out of a change in law potentially giving parties a civil claim against the issuing corporation. Of course, if the Commission had been aware, when it approved the stock, that 
ing the fairness of an offering must, of course, have access to the courts for equitable relief. ${ }^{41}$ But allegations of divestment possibilities provide no basis for claims of unfairness, particularly where authority to divest is denied by the agency approving the stock issue. ${ }^{42}$

Thus promoting neither aspect of the dual function of the ICC-protection of the consuming public and investors-a prior approval of control requirement also occasions an undesirable distortion of the judicial process. Consideration in stock authorization proceedings of the necessity for ICC approval of prior shifts in control entails judicial resolution of complicated legal questions without benefit of argument by suitable parties. ${ }^{43}$ Such determinations are particularly undesirable when made, in cases like Alleghany, by the same tribunal which would review a section $5(2)$ proceeding directly: the finding is not only binding precedent, it may preclude those with standing to raise the issue from doing so. ${ }^{44}$ Admittedly, rejecting review of section 5(2) deter-

it possessed the authority to divest Alleghany of Central due to illegality of control, it would have been negligent in not informing the public. Similarly, where a carrier proposing to issue stock is involved in significant litigation, see note 39 supra, if the issuance is authorized, the Commission should be required to disclose the nature and extent of the litigation to the potential investor. This may be done in the commission order of authorization. See Davis, Administrative Law 546 (1951) (ICC publishes reasoned opinions which in all respects resemble ordinary judicial opinions); ICC, REPORT 125 (1940) (settled policy of the ICC has favored the formulation of a detailed, reasoned report of its actions).

41. See note 28 supra; Alleghany Corp. v. Breswick \& Co., 353 U.S. 151, 159-60 (1957) (preferred stock issue threatening financial injury to minority shareholders suffcient to confer standing) ; cf. American Power \& Light Co. v. SEC, 325 U.S. 385 (1945) (shareholder could challenge order of SEC requiring corporation to make a transfer from surplus to capital account).

42. Whatever harm might result to shareholders from divestiture would not be caused by an otherwise fair issuance of securities. In Alleghany, the alleged illegal control existed independently of the proposed stock issue, and the dangers of divestment to existing shareholders were no greater or less because of it.

43. Under the Alleghany district court decision, any court affirmance of stock authorization must be taken as a silent holding that existing unapproved control relationships did not require approval under the statute. And if the danger of divestiture is suffcient, objecting shareholders will either not argue the issue of control or, if requested to by the court, will do so only perfunctorily. See note 30 supra. Furthermore, the ICC itself, seeking a favorable forum for review of its legal opinions on the necessity for control approval, might raise the question and rely on the fear of divestment to dampen any arguments of opposing stockholders. See note 29 stupra. Significantly, the latter possibility could arise under a narrow reading of the Supreme Court opinion as well as under the district court's decision. See text at notes 20-22 supra. In all such cases, the court would be forced to decide the statutory necessity of control approval, often an extremely complex issue, see note 32 supra, without strong argument that approval was required. For the potential effect of such decisions on those most interested in control determinations, see note 44 infra.

44. Conceivably, the district court could have, in examining the control of Central, concluded that ICC approval was not required under the act. See note 11 supra. Subsequently, despite the absence of a statute of limitations period, a competing carrier, shipper or other party with potential standing to contest $\$ 5(2)$ control determinations might 
minations in section 20 a proceedings may effectively deny shareholders standing to argue the control question. ${ }^{45}$ Deference to collateral rulings does not, however, conclusively bar judicial review of commission findings but merely forestalls it until the appropriate proceedings have been held. ${ }^{40}$ The Commission's special concern and expertise in the control issue heightens the undesirability of earlier review by minimizing the possibility of error and hence the advantages of review generally, as compared with cases in which the collateral issue is normally first tried in the courts. ${ }^{47}$

have difficulty in objecting to illegality of control in a direct proceeding, since the court would have already ruled on the contention collaterally.

45. In discussing reviewability at the suit of dissenting shareholders, the Supreme Court stated that Breswick might attack the status order only as it conferred jurisdiction on the ICC. See note 13 supra. The order did not, of itself, "pose any individualized threat to the welfare of appellees." Alleghany Corp. v. Breswick \& Co., 353 U.S. 151, 174 (1957). The claimed "dilution," however, was sufficient to allow Breswick to sue. The Court thus rejected the contention that the case of Pittsburgh \& W. Va. Ry. v. United States, 281 U.S. 479 (1930), governed the matter of standing. In Pittsburgh, a railway company proposed to sell its station and become a tenant in a new terminal. A minority stockholder railroad objected. The Supreme Court denied standing to contest the ICC order of approval; it stated that the stockholder's financial interest, though substantial, did not differ from that of every investor in the corporation's securities, "or from an investor's interest in any business transaction or lawsuit of his corporation. . . The injury feared [was] ... the indirect harm which may result to every stockholder from harm to the corporation." Id. at 487. The district court in Alleghany, however, did not base the injunction on an "individualized threat" to Breswick as a common stockholder but on the general injury to which all Alleghany investors would be subject-financial loss through an ICC order of divestment. Thus, the second district court opinion appears to have violated the Pittsburgh rule and to have granted Breswick standing to request an injunction on a theory considered and rejected in its first appearance before the Supreme Court. Cf. Davis, supra note 28, at 772-77. But see dissent of Mr. Justice Douglas, Alleghany Corp. v. Breswick \& Co., 26 U.S.L. WeEK 4116, 4119 (U.S. Jan. 27, 1958), note 19 supra.

For arguments in favor of increasing the parties with standing to contest agency decisions, see Davis, supra note 28, at 791-95. But see L. Singer \& Sons v. Union Pac. R.R., 311. U.S. 295 (1940) (inadvisable to allow any private interest to thrash out complicated questions before the agency).

46. Competitors can challenge $\$ 5(2)$ determinations in the courts. And shareholders are not denied standing if they establish a threatened individualized injury. See notes 28 , 41 supra. The court in Pittsburgh \& W. Va. Ry. v. United States, supra note 45, at 487 n.8, while denying standing, recognized that dissenting shareholders may in some circumstances sue and collected ICC cases in which shareholders were allowed to intervene: New York Cent., 72 I.C.C. 96 (1922) (preferred stackholders claiming price proposed for their stock inadequate); Nickel Plate, 105 I.C.C. 425 (1926) (minority interests not properly represented in merger); Cincinnati, I. \& W.R.R., 124 I.C.C. 476 (1927) (claim that fair share of benefits from proposed operational agreement denied minority shareholders); Southwestern Lines, 124 I.C.C. 401 (1927) (application for carrier control by stock purchase denied, since inadequate provisions made for rights of minority shareholders) ; Louisville, H. \& St. L. Ry., 150 I.C.C. 741 (1929) (minority stockholders objecting to rental terms of lease in which carrier control effected).

47. The Commission is the tribunal of the first instance in control determinations. See Schwabacher v. United States, 334 U.S. 182, 197 (1948) (jurisdiction of ICC under 
Judicial review of stock authorizations, accordingly, should not extend to prior shifts in control. Premature review usurps the discretionary powers of the agency to establish its own orderly procedure, based on its budgetary and personnel limitations. ${ }^{48}$ If these limitations in fact cause the ICC to be negligent in protecting the consumer from the dangers of illegal carrier acquisition, prompt investigation should be spurred by Congress, as the major regulatory force over administrative action, rather than compelled by the courts. ${ }^{49}$ Furthermore, since the investor is adequately protected by disclosure of the possible dangers in an issue, a reviewing court's proper function is simply to insure investor awareness of these dangers. Only when the ICC does not reveal attacks on an offering in authorization proceedings or its own contemplated future action testing carrier control should a court remand to the agency for disclosure of the facts. Properly construed, then, the Supreme Court's mandate justifiably precludes reversal of administrative regulatory determinations for errors of law collateral to the proceedings. The holding refutes the theoretical merit in subordinating stock authorizations to control controversies and offers adequate protection to both consumer and investor.

$\S 5$ is exclusive, plenary and independent of all other state or federal authority); cf. Thompson v. Texas M. Ry., 328 U.S. 134, 151 (1946) ; Rochester Tel. Corp. v. United States, 307 U.S. 125, 138-39 (1939) : "This court 'ascribed' to the findings of the Commission [FCC] the 'strength due to the judgments of a tribunal appointed by law and informed by experience' .... Recognition of the Commission's expertise also led this court not to bind the Commission to common law evidentiary and procedural fetters in enforcing basic procedural safeguards." On the ICC's expertise in determining control issues, see note 32 supra.

48. See note 31 supra. See also 2 Sharman, The Interstate Commerce ConsMIssion 480 (1931): "Since the primary objective [of Commission regulation] . . . is the protection and furtherance of the public interest, which is subject neither to precise definition as a general goal nor to automatic realization in concrete terms, the exercise of discretion becomes the dominant factor both in the disposition of applications, under the enabling powers, and in the adjudication of controversies under the directing powers."

"[J] udicial review ... has almost invariably served as a safeguard against the abuse of administrative authority, and not as an independent source of authority in the courts for molding the character and discretion of the regulatory process." 2 id. at 421.

49. In addition to increasing the Commission's appropriation, Congress might declare carrier control acquired without prior ICC approval void and require divestiture if application for approval is not made within a reasonable time. The only exception the Commission might then grant would be in cases where approval of control had been sought but refused as unnecessary under the statute. See note 34 supra. Further, substantial fines might be imposed on the violator. Such remedies would, however, decrease the important discretionary powers of the agency and, in arbitrarily compelling divestiture, possibly cause considerable injury to public transportation service. 